\title{
WHAT STRATEGIC STUDIES ARE AND ARE NOT: ABOUT A MANIFESTO BY ISABELLE DUYVESTEYN AND JAMES WORRAL
}

\section{ANTÓNIO HORTA FERNANDES} ahf@fcsh.unl.pt

Professor at the Department of Political Studies, Faculty of Social and Human Sciences, Universidade Nova de Lisboa (FCSH/UNL, Portugal). Researcher at the Portuguese Institute of International Relations (IPRI). National Defense Auditor. Strategist and polemologist.

\begin{abstract}
The present paper intends to make a synthetic update of the "being" of strategy, evoking strategic studies, namely in the aspects concerning the object of strategy and the relationship between strategy and politics. This update is done by confronting it with a recent manifesto, by Isabelle Duyvestein and James Worral, important for its repercussions on the science of international relations, which suffers from many weaknesses and no less aporias. It is important, therefore, to deconstruct some of its assumptions, which have also been those uncritically accepted when International Relations touches on the problematic inherent to strategic studies or focuses on war.
\end{abstract}

\section{Keywords}

Strategy, Politics, War, Subversive Warfare, Isabelle Duyvesteyn, James Worral

\section{How to cite this article}

Fernandes, António Horta (2021). What Strategic Studies Are and Are Not: about a Manifesto by Isabelle Duyvesteyn and James Worral. Janus.net, e-journal of international relations. Vol12, No. 1, May-October 2021. Consulted [online] at date of last visit, https://doi.org/10.26619/1647-7251.12.1.9

Article received on January 19, 2021 and accepted for publication on March 4, 2021

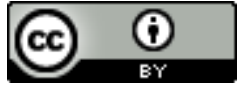




\title{
WHAT STRATEGIC STUDIES ARE AND ARE NOT: ABOUT A MANIFESTO BY ISABELLE DUYVESTEYN AND JAMES WORRAL ${ }^{1}$
}

\author{
ANTÓNIO HORTA FERNANDES
}

It is known that, within the scope of International Relations, strategic studies, or strategy, as we prefer to call it, have seen better days, to the detriment of critical security studies. However, we do not want to return to the debate on the confusion between strategic studies and security studies, already deserving attention from the Portuguese strategic school (Fernandes, 2015). Similarly, the ontological and epistemological insertion of strategy into the science of international relations is not a central point of this reflection. In fact, it is not a matter of a true insertion of strategy in International Relations, because strategy is a frontier knowledge. Even so, this subject has also been the subject of analysis within the Portuguese strategic school (Fernandes, 2010).

Rather, it is important to look at a reflection published in 2017 in the highly regarded Journal of Strategic Studies by two internationalists, Isabelle Duyvesteyn and James Worral, entitled Global Strategic Studies: a manifesto. The idea of a manifesto presented by the authors with cautious humility turns out to be short, because it is rather a true state of affairs - not the best of what is done in strategy, including in the Anglo-Saxon world, because names like Colin Gray, Beatrice Heuser or Lawrence Freedmann never appear, or rather, the most innovative of their contributions, this is not shown in the said manifesto - what appears as the most promising and updated in strategic studies, in order to converge with International Relations. Moreover, the authors summarize in an expeditious manner what passes for being the latest, or immediately to be, in the field, and what flows as good or even very good science on the treatment of hostility and war in International Relations, through the regional body of strategic studies. And that is precisely where the problem lies: the gain is scarce, the increase of confusion significant and the involution manifest. For this reason, it is important that such a record does not go unpunished, as if it were nothing, especially in Portugal, where not only the Journal of Strategic Studies has a wide audience in academic and military circles, but above all because there is a long tradition of studies on strategy, together with an innovative doctrinal and field practice, particularly in the sphere of subversive or insurrectional warfare.

\footnotetext{
${ }^{1}$ Article translated by Cláudia Tavares.
} 


\section{About the content of strategy definition}

The aforementioned manifesto begins by saying, passing for certain science, that strategy is an interdisciplinary field that "examines, at its core, the ways in which military power and other coercive instruments can be used to achieve political ends in the course of a dynamic interaction of at least two competing wills". ${ }^{2}$ We are, right from the start, facing a serious aporia. We are not referring to the possible meanings that competitive agonistics may have in English, possibly emphasizing regulated competition, which is quite difficult to integrate into the object of strategy. We even think that the expression "competing wills", perhaps not very rigorous, essentially means hostility, animoadversity, in a strong sense, between distinct actors of a political nature. The definition also does not refer to the political nature of the antagonistic wills, but the article as a whole goes in that direction entirely; in our view well - the full transposition of the strategic construct to non-political actors (e.g. economic), making them act prevalently around the issues of structuring political communities and their relations and power, would make them political actors, rather than of another nature (Duarte, 2004: 127-131).

The problem lies rather in the centrality given to the military vector. It is true that other instruments of coercion are mentioned, but the focus of the analysis is immediately placed on the military vector. Now, as is widely recognized, the military vector, which until more or less 70 years ago was the main axis not only practical but also theoretical of strategy, being, moreover, its foundational axis, is no longer so. In other words, the theory, for example, from Beaufre (Beaufre, 2004) to Abel Cabral Couto (Couto, 1988), to mention a couple of strategists who are today rightly considered classics, but also the practice, using as examples the strategy for subversive warfare and nuclear strategy, has evolved in the sense of considering, alongside military strategy, other general strategies, such as economic, diplomatic, cultural, and informational, among several others, all of which are subordinated to the great general maneuver of the political actor, known as integral strategy, without military power holding any primacy of principle. Military power is one among several instruments for the effective management of coercion, and this management as a whole dictates the use or non-use of military force. Moreover, in line with the evolution of warfare, which brought new modalities to the fore, other than armed coercion, technically dubbed cold war modalities, as they emerged, essentially, during the historical phase known as the Cold War.

It is clear that as far as war is concerned, there is a precision to be made. While in strategy, military strategy does not have any primacy at the level of fundamentals, moreover, there are even modalities of hostility that fall under the purview of strategy but are not yet war, neither hot nor cold, but rather hostile pressure (beyond all rules), the case of maneuvers on allies, on third parties of some peace support operations, certain sequences in subversive war, or the inverse strategies, which act in hostility by anti-hostility of means and almost of ends. When it comes to war, yes, there is a fundamental primacy of armed struggle. And why is this so? Not because it is a form of

2 In the original, the definition reads: "Strategic Studies is an inter-disciplinary field of studies, which at its core examines the ways in which military power and coercive instruments may be used to achieve political ends in the course of a dynamic interaction of (at least) two competing wills" (Duyvesteyn \& Worral, 2017: 347). 
struggle conceptually superior to the others, which would immediately transform them into forms of infra-warfare, completely upsetting the ontological and epistemological valuation of contemporary warfare, first because it is the armed struggle that most lends itself to the unleashing of violence without quarter, the general fire caused by the spread of violence, the ultimate chaos that sets the price of the warlike phenomenon and allows it to acquire singularity - a phenomenon generally designated by the conceptual syntagma absolute war ${ }^{3}$.

One could object that, as with the Portuguese Strategic Concept of National Defense (CEDN) of 2004, Isabelle Duyvensteyn and James Worral's definition merely states an accepted fact: after years of unrealized high expectations, the other general strategies, except the military one, have not yet reached the architectural level inherent to military strategy. However, the authors' definition is a basic conceptual proposal and not just a conjunctural adjustment. Moreover, the different national strategic concepts, such as the Portuguese one of 2004, have been adjusting themselves to the conjuncture; they were signaling that they included all the general strategies in an integrated way, but as their bones were not yet sedimented, they could not present as such what was not yet reality. On the other hand, what the 2004 Concept also seemed to want was to revalue the Armed Forces as a support arm of the State's foreign policy, in missions that evolved beyond the classic war operations. But let us make no mistake: the theoretical scope of the various strategies is perfectly established and pacific, although there has not always been the art, the ingenuity, the will or the fortune to realize this theoretical endeavor. Thus, as the military tends to resurface, in a new sense, remarkably close to diplomatic strategy, in addition to the increase in non-combat missions accompanying the upsurge of subversive wars, whatever name we want to give them today, it was and is easy, if less attentive, to confuse strategy with its exclusively military aspect.

At first sight, our authors' confusion would be very typical of Anglo-American strategic thinking or influenced by it. However, through Liddell Hart's seminal concept of grand strategy, the English strategist himself, as well as Beatrice Heuser, Colin Gray, or Edward Luttwak, go further and tend to consider these other coercive instruments with much greater vigor. Colin Gray defines grand strategy, the closest Anglo-Saxon term for integral strategy, as follows:

"the direction and use made of many or all of the assets of a security community in support of its political goals, as decided by politics. The theory and practice of grand strategy is the very theory and practice of the state apparatus." (Gray, 2010: 18).

Beatrice Heuser says it is difficult to find a universally valid definition of strategy through the ages. Nevertheless, she concludes, based on the results obtained by successive generations of strategists and strategists, that strategy is an overall path through which one seeks to achieve political ends, including the threat or effective use of force, within a dialectic of wills (Heuser, 2013: 27).

3 On the importance of absolute warfare in contemporary warfare, see the outstanding polymath and polemologist Nil Santiáñez (Santiáñez, 2020) (Santiáñez, 2018). 
In Colin Gray's case, it can be seen that in order to accommodate different forms of struggle, and more, so that there is no military predominance in the definition, the author is forced to almost evacuate the agonism of strategy, making the grand strategy coincide with the general and global action of the state as a whole, which, even assuming rational realism, is not reduced to objectives likely to create hostility on the part of another political will. It is as if in order to focus on the struggle itself the military vector must again be tacitly privileged. In relation to Beatrice Heuser, once again one runs the risk of evacuating agonism, were it not for the importance given to the dialectic of wills, but still opening the door to consider all agonism, both hostile and regulated competitive. More importantly, however, although the German-born strategist does not mention which use of force she is referring to and can therefore extend to forms of confrontation other than armed struggle, the body of work in question devoted to the history of strategy and strategic thought ultimately focuses on military strategy, including the 20th century.

After all, where do all these aporias in Anglo-American thought derive from, which not even the most astute strategists can get rid of? We think that the Anglo-American schools are still too stuck on Liddell Hart's theses. The British strategist distinguishes pure strategy, which is, at bottom, military strategy, from grand strategy, as concerning politics in the act in the face of hostile conflict (Liddell Hart, 1991) ${ }^{4}$. Defense policy (accentuating the military vector) and integral strategy thus appear amalgamated, and if contemporary Anglo-Saxon scholars are perfectly aware that strategy today integrates other dimensions that are not exclusively military, As we have already mentioned, when they refer to strategy per se, still the result of a deepening of the realist and rational theories inherited from Liddell Hart, they think above all of the military apparatus, or if we wish, of hard power, tending to place strategy at the military level. Now, as it is not always clear for them (even when they are aware that strategy and military strategy do not overlap) if, in the final analysis, strategy does not refer to the military and grand strategy to a defense policy leaning lately on the military vector, the ambiguity remains. This is because, ultimately, Anglo-American literature ends up overlapping war and strategy, through the operational military vector. The latter, in turn, is largely read through the guidelines of conventional warfare, in the context of hot war, and the idea of combat, especially classical combat, as an almost exclusive reason for the use of armed forces.

\section{The relationship between policy and strategy}

Moreover, on the relationship between strategy and politics, a decisive aspect of the structural framework of strategy, the position of Isabelle Duyvesteyn and James Worral is unclear, especially since the mediation of grand strategy does not appear, limiting the authors to a few considerations of practical international politics. Although we would not

4 The original of the work, as it appears edited and titled today, dates from 1954. It is there that the English strategist revises and adds a first version of the work, dated 1929, then entitled, The Decisive Wars of History, in which strategy is presented as military strategy. In 1954, his thinking evolves, particularly with the advent of nuclear power, adding a fourth part to the work, in which he begins to consider in addition to military strategy, now called pure strategy, a grand strategy as a defense policy in act. It was also around this time that Liddell Hart began to interpret the indirect strategic style as one that relied predominantly on non-military strategies, at the grand strategy level, thus overcoming his previous conception, according to which indirect strategy was nothing more than operational military strategy of indirect approach. It is also worth mentioning a new edition, dated 1967, where Liddell Hart adds a chapter on guerrilla warfare. 
be surprised if it were very close to those we have just mentioned, revealing a tendency for politics and strategy to overlap when defining, at the top level, the objectives to be attained and the rules of procedure in the face of existing or future confrontation. Something that may become worrisome in times of war, since war creates its own objectives and facilitates the temptation to invert the strategic pyramid, making politics subservient to strategic objectives, against its good performance, against what it wants as a discipline of intermediate ends and not merely instrumental, and for political responsibility. Strictly speaking, strategy aims to create conditions for the attainment of political objectives that arouse or may arouse hostility on the part of another political will, with a retroactive effect on politics, but always with a view to maintaining its proper place subordinated to the higher political synthesis. This higher political synthesis which weighs the objectives relating to hostility against all the other objectives, whether those relating to cooperation, accommodation, or competition, in order to achieve the political and supra-political ends that guide a given political community. When the governing bodies of strategy, now the same as those of policy, consider what is called (reductively) a defense strategy, they consider and then decide on hostility itself. When the governing bodies of policy (the same as those of strategy) consider defense policy (again a reductive expression), they consider and decide on hostility in correlation with all other objectives.

Expressed in another way, we can say that strategy is a discipline of incomplete ends, to be completed in the higher political synthesis. By this way of specific but incomplete strategic ends, strategic objectives are as strategic qua strategic as political objectives, necessarily intermediate and subordinate. Despite the strategic specificity, we are talking about the same community or social, the same actor that operates politically, inserting himself in the field of political hostility, and knowing that the strategy, in its vertical framework, dispatches ever closer to politics - nowadays the person responsible for the integral strategy and the political decision-maker are the same person, but with different functions, as we said above. The strategist, at the level of integral strategy, is the political decision-maker, and his informing staff, at the very moment he gives directives and dispatches due to hostility qua hostility, aroused by certain political objectives.

However, strategic objectives do not overlap or coincide in totality with the political objectives that arouse or may arouse hostility, because the punishment exercised by hostile conflict, especially war, by altering the normal social process, generates unique goals, in the sense of obliging politics to frame this violent punishment in the set of community objectives and goals, that is, to overdetermine the management of violence in order to avoid its solipsistic presence - it is not unusual for strategy to retroact upon politics in order to correct the latter's pro-war blindness. On the other hand, looking from a strictly political point of view, and without prejudice to the fact that the reference of strategy to politics, in theory, relativizes hostility, since it is framed by the other political objectives that are not exhausted in it, the political objectives that are susceptible to hostility must remain active and autonomous in relation to strategy in order to be weighed with the others: with those related to cooperation, accommodation, or competition. In the final analysis, politics may want to valorize them more, or deeply relativize them, as a superior synthesis, beyond, independently and even in spite of the recursive weighting exercised by strategic social rationality on the political domain tout court - it may well be that politics accepts, to be sure, the prudential rationalization of strategy (in the sense of phronesis), the outputs of strategic social rationality, but 
pretends to stop there, to stick to the incomplete ends of strategy, to become subservient to strategy, despite its will to the contrary. When you do not even want to pervert this prudence to promote a more sophisticated and refined hostilization, which instead of controlling damages increases them, but in a subtle way.

\section{Strategic Extensions}

Isabelle Duyvesteyn and James Worral suggest strategists take more seriously the criticism leveled at them from International Relations, that strategy studies seems to be just the arm's length of realist theories; either they lack fresh thinking or new perspectives (Duyvesteyn \& Worral, 2017: 348). However, how to take such criticism seriously? Strategy is older than the science of international relations, its foundations and schools of interpretation are specific. If there are authors with affinity to realism, perhaps an Aronian realism in the case of Beaufre or Abel Cabral Couto, and others who are averse to realism, especially in the Portuguese strategic school, some more are difficult to identify in any of the International Relations theories, for example Beatrice Heuser, or Lucien Poirier. On the other hand, having to deconstruct all the rhetorical gains that security studies have made about the object of strategy is already a major concern. Let us remember that the object of strategy is hostility between distinct political actors (or, in the case of internal wars, arrogating that the other is one of them). Thus, the field of hostility on the international scene is the operative field of strategy. This is not to say that hostility and strategy are not related to other factors, such as resource geopolitics, power politics, etc. But the field itself, in its fundamentals, in its specific modes of action, that is, the management of hostility itself, is the domain of strategy, subordinate to politics. Therefore, an informed interpretation of the international scene from this specific prism, that is, only and only from this prism, is only within the reach of strategic thinking, by no means, of security studies.

Isabelle Duyvesteyn and James Worral also assert that strategic studies, as important as states are, must promote a less statocentric approach (Duyvesteyn \& Worral, 2017: 348 ff.). At the same time they must look beyond classical conventional conflicts as the interpretative engine of strategic studies.

These rationales would come in very handy if they corresponded to the reality of strategic studies in the world (it will certainly still correspond to some Ptolemaic-inspired studies in a Copernican, even quantum, world, for the sake of the metaphor), and even to an exclusive look at history. Unfortunately, this is not the case. We do not know whether the authors have in mind the stereotype of the so-called Western way of waging war. But whether they have it in mind or not, it does not correspond to the evolution of war. In practice, we are talking about an Eighteenth-century ideal-typical that synthesizes the conventions created gradually throughout the Modern Age, concerning the confrontation of regular, uniformed armies, framed as such, under the ownership of state actors, fighting each other according to rules of maneuver, attrition, and engagement according to the battle, the sieges, and later, the sequence of battles. Now, knowing how short this history is in time and scope (as already shown by Clausewitz in Book VI of On War) and how non-state actors came back into play after World War II, contemporary strategists soon began to reflect on these non-state actors and on other modalities of war beyond conventional warfare, particularly on subversive warfare, or on the importance of 
structural, genetic, and declaratory strategies in the nuclear field, given the prominence of non-engagement strategies. Sun Tzu or Nguyen Van Giap have long been read, but by eyes that no less long have had good tools to read them.

Regarding subversive warfare, Duyvesteyn and Worral critically note that counterinsurgency, divorced from broader strategic imperatives, is not the silver bullet for such conflicts. Lastly, in a critical reference to David Kilcullen, against the consoling idea for Western public opinion that wars of this kind are a form of "armed social work". It seems, based on an absolutely clumsy article by Celeste Gventer, David Jones and MLR Smith about COIN - Counter-Insurgency - (Duyvesteyn \& Worral, 2017: 348). ${ }^{5}$ All these references are made, however, as if they were talking about last-minute discoveries and drifts.

Yes, but the comprehensive approach, and it needs to be well understood, is nothing more than the psycho-social action properly framed in the conquest of the minds and hearts of the population, isolating the subversive elements (or counter-subversive, if seen from the side of subversion) or even, if possible, making them bucket to the other side. However, this practice, doctrine, and adjusted reading of the nature of this typology of conflict is at least 60 years old. Subversive warfare is not and never has been a predominantly military conflict. It starts as an armed struggle, but at its core is the conquest of the population and not the military defeat of the insurgents or counterinsurgents, always subsidiary; much less the pure and simple annihilation of the antagonist, who emerges, as is known, in the middle of the population, at the risk of bringing about a terrible escalation, in a typology of conflicts already configuring multiple ramifications of an insidious nature. In fact, in the very definition of subversive ${ }^{6}$ war, which has been widely used and tested for many years (which is no less correct for that reason), when it refers not only to the de facto or de jure withdrawal of power from the authority, but only to the blocking of its action, it is clear that there is a margin of maneuver for that authority to draw the proper conclusions, a margin of de-escalation, of containment, and not the invitation to destroy the adversary at all costs, because this could be harmful to the conquest of the population, the core of the whole "game". In the

5 (Gventer, Jones \& Smith, 2015). The article in question wonders whether COIN is even a strategy, and answers in the negative. It is one thing for us to criticize Anglo-American counterinsurgency manuals for being too technocratic and still overly focused on the primacy of military strategy, out of relative misunderstanding of the "being" of strategy. Another is to call everything into question, without revealing the slightest knowledge of what subversive war is (which has two sides forced into competing actions), nor even of the very nature of strategy and war. Something even embarrassing considering that one of the researchers comes from the justly famous War Studies Department of King's College. One of the main explicit threads is that COIN does not keep in mind that war is always distinct. But not only is war distinct, so is politics, and ultimately so is everything in life; in which case nothing could be said or learned. Relativism, besides being self-contradictory and self-refuting, always ends up with mere grunt as its ultimate precipitate. An important implicit thread, if we read the text well, concerns the often dubiously inspired political motives behind both subversion and counter-subversion. But how important is this element in gauging the pertinence of the rational in the strategic reading of reality and in the effectiveness of action? Democracies or dictatorships, oppressors, and oppressed, just, and non-just people, can think well or badly, be more or less proficient. This is a matter concerning the ultimate ends of politics and not the level of strategy; even for a strategy as ethics of conflict (one should avoid the confusion of levels, as we have seen, common in Anglo-American thought). In war, victims are transmuted into executioners and viceversa. And even if we want to assume, without hesitation, there are bad guys and good guys, the bad guys don't always want war and the good guys want to avoid it.

6 Subversive warfare as the struggle conducted within a given territory, by part of its population, aided or not from outside (but almost always involving the external component), against the established de jure or de facto authorities, with a view to removing their power and control over that territory, or at least to paralyzing their action. 
same way, in military confrontation itself, brutality is not only unlawful, but also very dangerous because it can make the population understand how excessive we are. For if we claim to truly represent the population, but the adversary does not fail also to come out of the midst of it, disproportion can call into question the goodness of the argument, as they say in Law.

Perhaps intuitively and at the mercy of her intelligence, rather than of an in-depth knowledge of the subject, of which she perhaps does not possess, the Italian philosopher Donatella di Cesare, referring to the somewhat different figure of the resistant, draws a remarkable picture of subversive war when she affirms that the resistant, in our case, the insurgent.

He does not confront the enemy in order to defeat him, but rather defends himself against the adversary in order to force him to let go of his prey [- from the tactical perspective, because he still lacks strength, in the strategic component, the decisive one, in order to be able to shape his prey, the people, according to the principle of concurrent forces -]. He disarms it with his weapons, shakes up the rules, takes it by surprise, disorients it. It always tries in this way to regain space and time to reorganize itself. It does not want victory, except in the form of liberation [- it is not, therefore, military victory, but rather the bringing to itself, "liberating", the people -]" (Cesare, 2021:35). ${ }^{7}$

In light of this, to possibly insist on a military confrontation of diametrically opposed forces and not of concurrent forces seems even a little ridiculous.

Subversive warfare, as a time unit per mor of lassitude, is an insidious event, where one seeks to lead the enemy to conclude that even the closest, including the neighbor, the friend, the relatives may not be with him and, in the limit, he is the enemy of himself and of the community, and must therefore leave or join the subversive forces. In other words, calling to mind Mia Couto's most recent novel:

"The enemy is the manservant that takes care of our children. It is the official who sits next to us. The enemy is we ourselves who don't know how long we can resist." (Couto, 2020:226).

It is true that Mia Couto is not just any writer, he has a long and deep digression on war in his novels, but his choice for us is not innocent. It means how much the nuclear elements of subversive warfare have been concentrated and taken as basic, to the point that a good tirade from a novel could illustrate them without more, without the need of great theoretical supports; as Donatella di Cesare was already doing, in a certain way, in the past. Thus, Duyvesteyn and Worral's writing of a manifesto to promote the invention of the wheel (or more likely, to discredit it, if the authors truly understood it) is, to say the least, unusual.

The authors also refer to the need to set aside the one-sidedness of rational choice analyses, more or less behaviorist, including a fair allusion to Clausewitz (Duyvesteyn \& Worral, 2017: 349). ${ }^{8}$ Once again we are faced with redundancy. It has long been the case that strategy, precisely to account for the asystematic nature of the war

The italics are ours.

8 On this point, see Alan Beyerchen's magnificent study (Beyerchen, 1992-93), and also (Engberg-Pedersen, 2015). 
phenomenon and the freedom that characterizes human action, has put into play art, including aesthetic rationales, intuition, savoir-faire and, above all, sagesse, the practical wisdom, that compenetration with the world, an immersive knowledge breaking through reality from below and vice versa, fundamental to an area that not only makes up a field of studies, with its own methods and objectives, with a specific object and therefore with a regional ontic substratum, but is above all a praxis, a very specific response of political communities to the injunctions dictated by the exceptionality of hostile conflict, particularly war.

Strategy is the practical wisdom in the service of politics, obviously in a normative, ethical, prudential sense, in the sense of phronesis, that manages hostile conflict, which has its marginal utility value in war, with a view not only to achieving victory, mitigating defeat, or negotiating an acceptable stalemate, but first and foremost to implode hostile conflict itself from within and forever. In essence, the path of strategy as ethics of conflict, which is also a motive for meditation and debate in the Portuguese strategic school. Here too, Isabelle Duyvesteyn and James Worral have little to say in terms of innovation with their own definition and consequent glossing of a so-called broad approach to strategic studies. It is that a definition of strategy cannot be reduced to its operative lion's share, the integral strategy, as important as this is, and it is. Integral strategy is not strategy by antonomasia. Strategy must also consider what Jean-Paul Charnay called metastratégie (Charnay, 1990a: 188-189) (Charnay, 1990b: 213 and ff.) and Lucien Poirier called stratégique (Poirier, 1987: 195, 199-201). ${ }^{9}$ Reflection on the nature of strategy and its intrinsic evolution, its particular epistemological framework (its mode of production), the meaning of strategic action in relation to political ends and supra-political ends are also concretizations of strategy. We would say that they are fundamental concretions of the strategy, without which the integral strategy would have no north, because it would not be anchored in the integral, whole reality. It is for this last reason that we do not think it is lawful, pace the two renowned French strategists, to evoke these concepts to include the non-operative dimensions of strategy in a separate spectrum, in which the strategy itself, the stratégie, would then only concern the strategic action and its direct surroundings, the strategic environment. In our view, that would be to deprive the strategy of core dimensions, not external, but internal, basic to its praxist core.

For the rest, and with respect to the idea of strategy as a praxis discipline, ethics of conflict, art of prudence beyond prudence, there is a point in Isabelle Duyvesteyn's and James Worral's discourse that is conspicuous by its absence, but which is even capable of having important strategic operational repercussions. We refer to the relationship between strategy and the environment, and not only as an analog model, although with all due care, because war, which is damaging to everything, is also damaging to the ecosystem. Strategy may well be an analog model for environmental campaigns because its logic is to rationalize while avoiding the senseless squandering of human and material resources. A frugality that is also inherent, for operational and logistical reasons, to military actions. In fact, as far as military action itself is concerned, it is not only a matter of optimizing resources, doing more with less, not degrading the environment. The armed instrument itself can be too heavy to be used in certain conflicts, called low-intensity

9 Interestingly, the term stratégique gave origin to the most important journal of the same name dedicated to strategy. 
conflicts. But no less important in the realm of perceptions, the declaratory strategy is the ecological footprint left behind, which can be perceived as the fruit of an arrogant and clumsy posture, alienating support.

However, we must go further. If we think that strategy also acts on the hostility to be had, and that actions of apparently pure environmental incidence are not only a strategic risk, but perhaps also a threat, and may be the cause of a hostile perception, because even if they are not considered and carried out with the intention of harassing another actor, there is nevertheless today a perfect awareness of the damage (for example, the fossil fuel race in the Arctic). Therefore, strategy as conflict ethics, aiming to limit and defuse potential conflicts, as a prudential attitude towards the other and towards oneself, is, in this sense, also an (ethical) action of openness to the other, with direct environmental incidence. Because in its model of frugality, of rationalization, of phronetic weighing of resources, as it seeks to contain in just measure or defuse conflicts over the environment, it does so by defusing aggressive environmental postures, contributing to the idea of the common home. ${ }^{10}$

It would be good for internationalists to read the manifesto in question in order to understand, not the state of play of strategic studies or of an upcoming renewal, but how skewed this formulation of strategy is, how reductive and even redundant it is, looking instead at what innovative work has been done nationally and internationally in the field of strategy studies for at least 60 to 70 years. The biggest problem for International Relations is that perspectives such as this one, as well as that of security studies, have left those same International Relations captive to an understanding that is not only erroneous but also tame and as if it were frayed velvet, not only of the meaning of strategic studies, but, above all, of the reality of international conflict, especially of war, unfortunately still so pervasive in the international scene.

\section{References}

Beaufre, André (2004). Introdução à Estratégia [portuguese trad.] Lisboa: Sílabo.

Beyerchen, Alan (1992-93). "Clausewitz, Nonlinearity and the Unpredictability of War". International Security, 17:3, pp.59-90.

Cesare, Donatella di (2021). O Tempo da Revolta, Lisboa: Edições 70.

Couto, Abel Cabral (1988). Elementos de Estratégia. Apontamentos para um curso, 2 vols. Lisboa: IAEM.

Couto, Mia (2020). O Mapeador de Ausências. Alfragide: Caminho.

Duarte, António Paulo (2004). "Os (De)limites da Estratégia. Assomos reflexivos a propósito de um debate estratégico teórico" in Francisco Abreu e António Horta Fernandes, Pensar a Estratégia. Do político-militar ao empresarial. Lisboa: Sílabo, pp. 123-138.

10 These ideas, outlined here in a still embryonic way, were suggested to us by Abel Cabral Couto, following an oration of wisdom delivered by Viriato Soromenho-Marques, at the inaugural session of the academic year of the National Defense Institute, in 2019. 
Duyvesteyn, Isabel e Worral, James (2017). "Global Strategic Studies: a manifesto". Journal of Strategic Studies, vol.40, Issue 3, pp. 347-357.

Engberg-Pedersen, Anders (2015). Empire of Chance. The napoleonic wars and the disorder of things. Cambridge, Mass: Harvard University Press.

Fernandes, António Horta (2010). "A Estratégia e as Relações Internacionais". Nação e Defesa, no 36, pp. 87-104.

Fernandes, António Horta (2015). "O Conceito de Segurança. Um obstáculo à paz". Relações Internacionais, n048, December 2015, pp. 139-164.

Gray, Colin (2010). The Strategy Bridge: theory for practice. Oxford: Oxford University Press.

Gventer, Celeste Ward, Jones, David Martin e Smith, MLR (2015). "Desconstructing Counter-Insurgency: COIN discourse and the devaluation of strategy". Cambridge Review of International Affairs, 28:3, pp. 348-372.

Hart, Basil Liddell (1991). Strategy. New York: Penguin.

Heuser, Beatrice (2013). Penser la Stratégie de l'Antiquité à nos Jours [french trad.]. Paris: Picard.

Santiáñez, Nil (2018). Wittgenstein's Ethics and Modern Warfare. Walterloo, Ontario: Wilfrid Laurier University Press.

Santiáñez, Nil (2020). The Literature of Absolute War. Transnationalism and World War II. Cambridge: Cambridge University Press. 